Louisiana State University

LSU Digital Commons

Faculty Publications

Department of Biological Sciences

$1-15-2016$

\title{
The modulation of adiponectin by STAT5-activating hormones
}

Ursula A. White

Pennington Biomedical Research Center

Joel Maier

Louisiana State University

Peng Zhao

Pennington Biomedical Research Center

Allison J. Richard

Pennington Biomedical Research Center

Jacqueline M. Stephens

Pennington Biomedical Research Center

Follow this and additional works at: https://digitalcommons.Isu.edu/biosci_pubs

\section{Recommended Citation}

White, U., Maier, J., Zhao, P., Richard, A., \& Stephens, J. (2016). The modulation of adiponectin by STAT5-activating hormones. American Journal of Physiology - Endocrinology and Metabolism, 310 (2), E129-E136. https://doi.org/10.1152/ajpendo.00068.2015

This Article is brought to you for free and open access by the Department of Biological Sciences at LSU Digital Commons. It has been accepted for inclusion in Faculty Publications by an authorized administrator of LSU Digital Commons. For more information, please contact ir@lsu.edu. 


\title{
CALL FOR PAPERS $\|$ Novel Aspects of Adipocyte Biology
}

\section{The modulation of adiponectin by STAT5-activating hormones}

\author{
Ursula A. White, ${ }^{1}$ Joel Maier, ${ }^{2}$ Peng Zhao, ${ }^{1,2}$ Allison J. Richard, ${ }^{1}$ and Jacqueline M. Stephens ${ }^{1,2}$ \\ ${ }^{1}$ Adipocyte Biology Laboratory, Pennington Biomedical Research Center, Baton Rouge, Louisiana; and ${ }^{2}$ Department of \\ Biological Sciences, Louisiana State University, Baton Rouge, Louisiana
}

Submitted 12 February 2015; accepted in final form 23 November 2015

White UA, Maier J, Zhao P, Richard AJ, Stephens JM. The modulation of adiponectin by STAT5-activating hormones. Am J Physiol Endocrinol Metab 310: E129-E136, 2016. First published November 25, 2015; doi:10.1152/ajpendo.00068.2015.-Adiponectin is a hormone secreted from adipocytes that plays an important role in insulin sensitivity and protects against metabolic syndrome. Growth hormone $(\mathrm{GH})$ and prolactin (PRL) are potent STAT5 activators that regulate the expression of several genes in adipocytes. Studies have shown that the secretion of adiponectin from adipose tissue is decreased by treatment with PRL and GH. In this study, we demonstrate that 3T3-L1 adipocytes treated with GH or PRL exhibit a reduction in adiponectin protein levels. Furthermore, we identified three putative STAT5 binding sites in the murine adiponectin promoter and show that only one of these, located at $-3,809$, binds nuclear protein in a GH- or PRL-dependent manner. Mutation of the STAT5 binding site reduced PRL-dependent protein binding, and supershift analysis revealed that STAT5A and -5B, but not STAT1 and -3 , bind to this site in response to PRL. Chromatin immunoprecipitation (IP) analysis demonstrated that only STAT5A, and not STAT1 and -3, bind to the murine adiponectin promoter in a GH-dependent manner in vivo. Adiponectin promoter/reporter constructs were responsive to $\mathrm{GH}$, and chromatin IP analysis reveals that STAT5 binds the adiponectin promoter in vivo following GH stimulation. Overall, these data strongly suggest that STAT5 activators regulate adiponectin transcription through the binding of STAT5 to the $-3,809$ site that leads to decreased adiponectin expression and secretion. These mechanistic observations are highly consistent with studies in mice and humans that have high GH or PRL levels that are accompanied by lower circulating levels of adiponectin.

signal transducer and activator of transcription 5

GROWTH HORMONE (GH) is known to have profound effects on adipocyte metabolism (reviewed in Ref. 8), such as attenuating lipogenesis and stimulating lipolysis $(35,56)$. The effects of prolactin (PRL) have been well characterized in mammary tissues, and yet there is also evidence suggesting that this hormone can act within adipose tissue in mice and humans (31, $36)$ to modulate lipolysis $(11,32)$. It is well known that GH and PRL induce signaling via the JAK/STAT pathway, and STAT5 proteins are potently activated by these hormones (reviewed in Ref. 46). However, few direct molecular targets for the actions of GH and PRL in fat cells have been identified.

Multiple lines of evidence suggest that STAT5 proteins can modulate adipocyte function. During differentiation of 3T3-L1 adipocytes, the expression levels of STAT5A and $-5 \mathrm{~B}$ are highly induced (50). In addition, GH-dependent adipogenesis

\footnotetext{
Address for reprint requests and other correspondence: J. M. Stephens, Pennington Biomedical Research Center, Adipocyte Biology Laboratory, Baton Rouge, LA 70808 (e-mail: jsteph1@1su.edu).
}

of 3T3-F442A cells is attenuated by STAT5 antisense oligonucleotides (58), and constitutively active STAT5 can replace the requirement for $\mathrm{GH}$ in adipogenesis of these cells (48). Moreover, ectopic expression of STAT5A has been shown to confer adipogenesis in both 3T3-L1 preadipocytes (38) and in nonprecursor fibroblast cell lines (12). Transgenic deletion of STAT5A, STAT5B, or both STAT5 genes in mice results in significantly reduced fat pad sizes compared with wild-type mice (53). Other in vivo studies indicate that fibroblasts ectopically expressing STAT5 can form ectopic fat pads at the site of injection when injected into athymic mice (51). In primary cultures of adipose tissue from STAT5-null mice, GH is unable to stimulate lipolysis as it does in adipocytes from wild-type animals (10). Collectively, these studies and others (43) suggest that STAT5 proteins mediate some of the physiological effects of $\mathrm{GH}$ on fat cell differentiation and lipid metabolism.

Although evidence from numerous independent laboratories suggests that STAT5 proteins can modulate adipocyte physiology $(10,12,38,43,48,50,51,53,58)$, very few studies have identified direct STAT5 target genes in adipocytes. In previous studies, we observed that GH- or PRL-induced inhibition of fatty acid synthase (FAS) transcription was mediated by a STAT5A-binding site in the rat FAS promoter (18). In addition, the promoter for acyl-CoA oxidase, the rate-limiting enzyme in peroxisomal fatty acid $\beta$-oxidation, contains a STAT5 binding site that increases its gene expression in fat cells as a result of treatment with $\mathrm{GH}(7)$. We also identified a STAT5 binding site in the murine pyruvate dehydrogenase kinase 4 (PDK4) promoter that mediates the PRL and $\mathrm{GH}$ induction of PDK4 expression in adipocytes (57). PDK4 expression is associated with decreased insulin-responsive glucose uptake in these cells (57) and may correlate with $\mathrm{GH}$ induced systemic insulin resistance. Our current efforts are to identify other genes associated with glucose or lipid metabolism that are directly modulated by STAT5 proteins in fat cells.

Adiponectin is an adipokine that plays an important role in the regulation of glucose, lipid, and energy metabolism (21, $45)$ by suppressing hepatic gluconeogenesis and increasing insulin sensitivity (reviewed in Ref. 54). Low serum levels of adiponectin are associated with obesity and insulin resistance in both animals and humans $(1,19,20,30,39)$ (reviewed in Ref. 16). Adiponectin administration can alleviate insulin resistance (13). Some studies have shown that STAT5 activator GH or PRL can reduce the production and secretion of adiponectin. Mice treated with bovine $\mathrm{GH}$ have decreased total and high-molecular weight adiponectin (34). In cultured human adipose tissue, adiponectin secretion is significantly suppressed by PRL (40). In transgenic animal models with increased GH signaling, circulating levels of adiponectin are 
Table 1. STAT consensus sequences in the adiponectin promoter

\begin{tabular}{lcc}
\hline \hline \multicolumn{1}{c}{ Position } & Sequence & PRL Responsive? \\
\hline$-3,196$ & TTCTCAGAA & No \\
$-3,394$ & TTCGGAGAA & No \\
$-3,809$ & TTCTGGGAA & Yes \\
$-3,809$ (mutant) & TTAAGGGAA & No \\
$\beta-$-Casein & TTCTAGGAA & Yes \\
\hline
\end{tabular}

PRL, prolactin.

decreased. Conversely, mice lacking the GH receptor or expressing a GH antagonist have increased circulating levels of this hormone (3). Serum adiponectin levels are reduced in patients with acromegaly and normalized after correction of GH excess (29). Also, patients with high circulating PRL due to prolactinomas have hypoadiponectinemia $(9,14)$. Collectively, these results suggest that GH and PRL, two STAT5activating hormones, can inhibit adiponectin expression and/or secretion in mouse and man.

The primary objective of our study was to determine whether GH and PRL could modulate adiponectin expression in a STAT5-mediated manner. We examined the modulation of adiponectin by STAT5 activators in adipocytes. Our studies clearly demonstrate that both GH and PRL inhibit adiponectin expression and production in fat cells. We identified three putative STAT-binding elements in the adiponectin promoter and show that only one of these sites specifically and significantly binds STAT5 in vitro and in vivo. Chromatin immunoprecipitation (ChIP) analysis and mutagenesis studies indicate that STAT5 binds the adiponectin promoter in vivo, and attenuation of adiponectin transcription is dependent upon the STAT5 binding site that we validated. However, the adiponectin mRNA is very stable, and changes in adiponectin transcription are not evident at the protein level for several days after treatment with STAT5-activating hormones. These novel studies provide highly mechanistic data that support numerous studies showing that elevated GH and PRL can reduce adiponectin expression in both mice and humans.

\section{MATERIALS AND METHODS}

Materials. Dulbecco's modified Eagle's medium (DMEM) was purchased from Sigma. Fetal bovine and calf sera were purchased from Hyclone. Commercial antibodies against STAT1 (Upstate Biotechnology), STAT3, and STAT5A (Santa Cruz Biotechnology) and adiponectin (ThermoFisher Scientific) were purchased. Murine GH and murine PRL were from ProSpec. Mouse tumor necrosis factor- $\alpha$ was purchased from Gibco (Life Technologies). Rosiglitazone was obtained from Cayman Chemical. $\left[\alpha-{ }^{32} \mathrm{P}\right] \mathrm{dCTP}$ and deoxynucleotides (dATP, dTTP, and dGTP) were purchased from GE Healthcare or Amersham Biosciences. Klenow fragment was from Promega.

Cell culture. Murine 3T3-L1 preadipocytes were plated and grown to 2 days postconfluence in DMEM with $10 \%$ calf serum. Medium was changed every $48 \mathrm{~h}$. Cells were induced to differentiate by changing the medium to DMEM containing $10 \%$ fetal bovine serum (FBS), $0.5 \mathrm{mM}$ 3-isobutyl-1-methylxanthine, $1 \mu \mathrm{M}$ dexamethasone, and $1.7 \mu \mathrm{M}$ insulin. This medium was replaced with DMEM containing $10 \%$ fetal bovine serum and $425 \mathrm{nM}$ insulin for $48 \mathrm{~h}$. Adipocytes were then maintained in DMEM with $10 \%$ FBS for $\geq 8$ days.

Preparation of whole cell extracts. Cell monolayers were harvested in a nondenaturing buffer containing $10 \mathrm{mM}$ Tris ( $\mathrm{pH} 7.4), 150 \mathrm{mM}$ $\mathrm{NaCl}, 1$ mM EGTA, 1 mM EDTA, $1 \%$ Triton X-100, 0.5\% Nonidet
P-40, $1 \mu \mathrm{M}$ phenylmethylsulfonyl fluoride, $1 \mu \mathrm{M}$ pepstatin, $50 \mathrm{mU}$ trypsin inhibitory aprotinin, $10 \mu \mathrm{M}$ leupeptin, and $2 \mathrm{mM}$ sodium vanadate. Samples were extracted for $30 \mathrm{~min}$ on ice and centrifuged at $15,000 \mathrm{rpm}$ at $4^{\circ} \mathrm{C}$ for $15 \mathrm{~min}$. Media samples were collected from adipocyte culture, and $1 \mu \mathrm{M}$ pepstatin was added prior to $-80^{\circ} \mathrm{C}$ storage. Supernatants containing whole cell extracts or media samples were analyzed for protein content by BCA analysis (Pierce) according to the manufacturer's instructions.

Nuclear and cytosolic extract preparation. Monolayers of 3T3-L1 adipocytes were harvested in a nuclear homogenization buffer, as described previously (60). Nonidet P-40 was added to a final concentration of $0.15 \%$, and cells were homogenized with 16 strokes in a Dounce homogenizer. Homogenates were centrifuged at 1,500 rpm for $6 \mathrm{~min}$ at $4^{\circ} \mathrm{C}$. The supernatants were saved and frozen as cytosolic extracts and the pellets of intact nuclei were resuspended in half of the previous volume of nuclear homogenization buffer and centrifuged as before. The resulting nuclear pellet was resuspended in a buffer of 20 mM HEPES (pH 7.9), $0.42 \mathrm{M} \mathrm{NaCl}, 1.5 \mathrm{mM} \mathrm{MgCl}_{2}, 0.2 \mathrm{mM}$ EDTA, and $25 \%$ glycerol. For electrophoretic mobility shift assays, the nuclear suspensions were incubated on ice for $\geq 30 \mathrm{~min}$ and then drawn twice through a 20 -gauge needle. The nuclear extracts were centrifuged for $10 \mathrm{~min}$ at $10,000 \mathrm{rpm}$, and supernatants were taken for protein analysis by BCA or stored in aliquots at $-80^{\circ} \mathrm{C}$.

RNA analysis. Total RNA was isolated from cell monolayers with Trizol (Invitrogen) according to the manufacturer's instructions, with minor modifications. For Northern blot analysis, $15 \mu \mathrm{g}$ of total RNA was denatured in formamide and electrophoresed through a formaldehyde-agarose gel. The RNA was transferred to Zeta Probe-GT

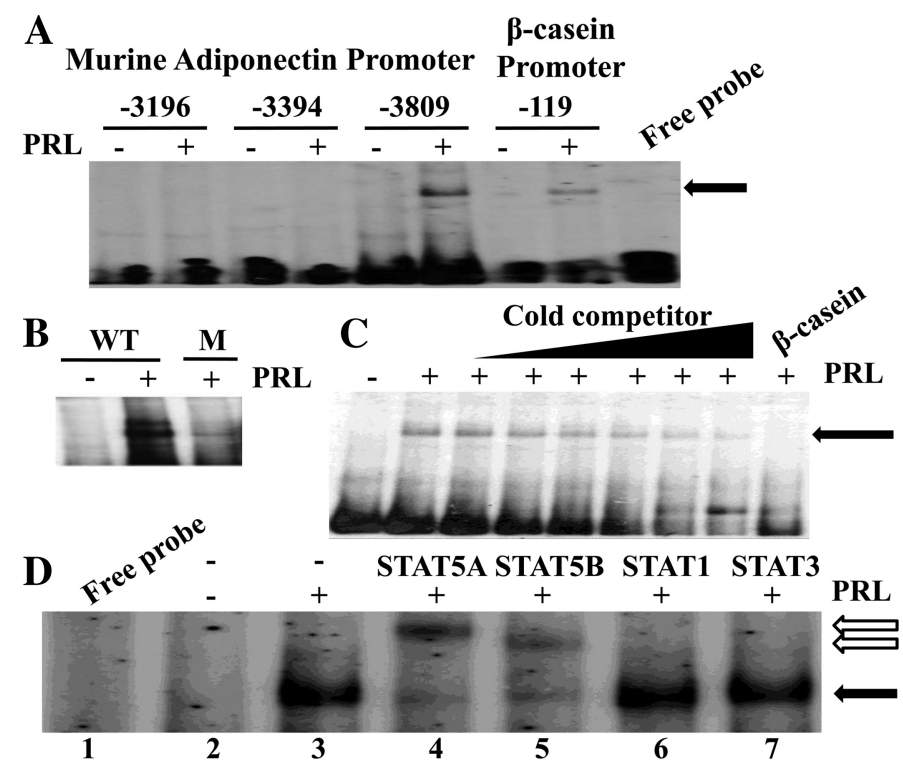

Fig. 1. The identification of a prolactin (PRL)-responsive region in the murine adiponectin promoter that binds STAT5A and STAT5B. A: nuclear extracts were prepared from adipocytes that were untreated $(-)$ or treated $(+)$ with 1 $\mathrm{nM}$ PRL for $15 \mathrm{~min}$, and protein-DNA complexes were resolved by electrophoretic mobility shift assay (EMSA). For each sample, $15 \mu \mathrm{g}$ of protein was incubated with 100,000 counts/min of the indicated ${ }^{32}$ P-labeled probes. $B$ : wild-type (WT) and mutant (M) probes (see Table 1) were incubated with $10 \mu \mathrm{g}$ of nuclear extract from PRL-treated cells and subjected to EMSA analysis. $C$ : ${ }^{32} \mathrm{P}$-labeled probes with an activity of 50,000 counts $\cdot \mathrm{min}^{-1} \cdot \mathrm{ml}^{-1}$ were serially diluted with $50 \mathrm{nM}$ to $5 \mu \mathrm{M}$ of unlabeled probe and combined with $10 \mu \mathrm{g}$ of PRL-treated nuclear extracts. Five micromoles of unlabeled $\beta$-casein probe was used as a positive control. Complexes were resolved by EMSA. $D: 10 \mu \mathrm{g}$ of PRL-treated nuclear extract was incubated with $1.5 \mu \mathrm{g}$ of the indicated STAT antibodies for $1 \mathrm{~h}$ at room temperature prior to incubation with 50,000 counts $\cdot \mathrm{min}^{-1} \cdot \mathrm{ml}^{-1}$ of radiolabeled $-3,809$ probe. Complexes were resolved by EMSA. $A-D$ represent experiments each performed individually 3 times. 


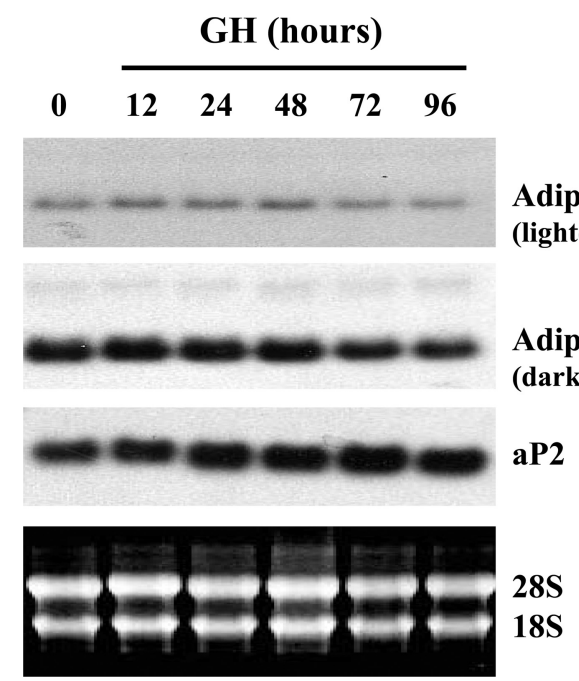

Fig. 2. Chronic growth hormone $(\mathrm{GH})$ treatment results in a modest decrease in adiponectin mRNA levels. Fully differentiated 3T3-L1 adipocytes were maintained in DMEM containing 10\% FBS and treated with $2 \mathrm{nM} \mathrm{GH}$ every $24 \mathrm{~h}$ until harvested at the times indicated. Following treatment, total RNA was collected from cells, and $20 \mu \mathrm{g}$ of each total RNA was electrophoresed, transferred to nylon, and subjected to Northern blot analysis. This is a representative experiment performed independently 3 times.

(Bio-Rad) in a buffer containing $75 \mathrm{mM}$ sodium citrate tribasic, 10 $\mathrm{mM} \mathrm{NaOH}$, and $750 \mathrm{mM} \mathrm{NaCl}$. Probes were labeled by random priming using Klenow fragment and $[\alpha-32 \mathrm{P}] \mathrm{dCTP}$.

Electrophoretic mobility shift assays. Double-stranded oligonucleotides were end-labeled with $[\alpha-32 \mathrm{P}] \mathrm{dCTP}$ using Klenow. Binding reactions were performed with nuclear extracts as described (44). Protein-DNA complexes were resolved and visualized as described previously (18). For cold competition analysis to determine specificity of binding, nuclear extracts were incubated on ice for 15 min with unlabeled oligonucleotide before the addition of ${ }^{32} \mathrm{P}$-labeled probe. For supershift analysis, nuclear extracts were preincubated with antibody for $1 \mathrm{~h}$ at room temperature.

Plasmid construction. The region corresponding to the $-3,809$ site and flanking regions were amplified by PCR. Restriction sites for NheI and HindIII were added to primer ends to facilitate directional cloning. PCR reaction conditions consisted of $45 \mu \mathrm{l}$ of platinum PCR supermix $\mathrm{HiFi}$ (Invitrogen), $0.5 \mu \mathrm{l}$ of each primer from a $20-\mathrm{pM}$ stock, and $100 \mathrm{ng}$ of genomic DNA from 3T3-L1 adipocytes. PCR was performed using an MJ Research PTC-100 machine set to cycle at 1) $94^{\circ} \mathrm{C}$ for $\left.2 \mathrm{~min}, 2\right) 94^{\circ} \mathrm{C}$ for $\left.30 \mathrm{~s}, 3\right) 55^{\circ} \mathrm{C}$ for $30 \mathrm{~s}$, and 4) $68^{\circ} \mathrm{C}$ for $4.5 \mathrm{~min}$, which was then repeated 35 times beginning with step 2 . Amplicons were purified and digested with NheI and HindIII according to the manufacturer's instructions (New England Biolabs). The pGL4.27 luciferase vector (Promega) was also digested with NheI and HindIII and ligated to previously digested amplicon by using T4 DNA ligase according to the manufacturer's instructions (New England Biolabs) to create adiponectin promoter/luciferase reporter pGL4 vectors. The STAT consensus sequence in the vectors was mutated to alter the binding site (refer to Table 1) using the QuickChange II Site Directed Mutagenesis kit (Stratagene). Plasmids were sequenced for verification of wild-type and mutagenic nucleotide sequences using Big Dye Terminator Extension Reactions (ABI).

Transfection of 3T3-L1 adipocytes. Six-well plates of 3T3-L1 cells were transfected on day 3 of differentiation after addition of DMEM containing 5\% FBS. Cells were cotransfected with $2.5 \mu \mathrm{g}$ of a plasmid containing $4.5 \mathrm{~kb}$ of the adiponectin promoter $2-\mathrm{kb}$ fragment containing the $-3,809$ site and $250 \mathrm{ng}$ of pGL-TK/renilla vector to control for transfection efficiency using Fugene 6 (Roche). Cells were maintained in the presence or absence of $1 \mathrm{nM}$ murine GH. Thirty hours posttransfection, cell lysates were harvested and assayed for firefly and Renilla luciferase using the Dual Luciferase Reporter System (Promega). Relative light units were calculated by dividing firefly luciferase activity values by Renilla luciferase.

Chromatin immunoprecipitation. A SimpleChIP enzymatic ChIP kit (Cell Signaling Technology) was used for the ChIP assay. Mature 3T3-L1 adipocytes were serum deprived overnight. Cells were treated with murine $\mathrm{GH}$ for $30 \mathrm{~min}$ and then cross-linked with formaldehyde and glycine. Chromatin extracts were prepared according to the manufacturer's protocol. The STAT5A antibody used for immunoprecipitation was purchased from Santa Cruz Biotechnology. Purified DNA was quantified by real-time PCR with SYBR Green Supermix and ROX buffer (Takara). Real-time PCR was performed with following primers: CTGTAGCTATACTGATGGTTGTGAGCC (forward) and CTTTAGACTGGAGCAACTGGAGCC (reverse). The formula used to calculate the percentage of input was as follows: $\%$ input $=2 \% \times 2\left(\mathrm{C}_{\mathrm{T}} 2 \%\right.$ input sample $-\mathrm{C}_{\mathrm{T}}$ IP sample $) \times \mathrm{k}$.

\section{RESULTS}

GH and PRL are potent STAT5 activators, and evidence suggests that these hormones alter circulating adiponectin levels; thus we hypothesized that the adiponectin promoter contains putative STAT5 binding sites that confer GH and/or PRL responsiveness. We cloned the murine adiponectin promoter and searched for the presence of STAT consensus sites. Sequence analysis confirmed that the cloned promoter was $100 \%$ homologous to Genbank NT_039624.7 Typically, STAT proteins bind a core palindromic sequence, TTC NNN GAA, but selective variation can occur in particular nucleotide positions. As shown in Table 1, an analysis of the murine adiponectin promoter resulted in the identification of three sites with substantial homology to the STAT consensus sequence.

To evaluate these potential STAT binding sites, we performed a series of electrophoretic mobility shift assays (EMSAs). For these experiments, an oligonucleotide probe containing $9 \mathrm{bp}$ of the core STAT motif with $6 \mathrm{bp}$ of flanking sequence on either end was incubated with nuclear extracts prepared from 3T3-L1 adipocytes that were untreated or treated acutely with PRL for 15 min. As shown in Fig. 1A, PRL did not induce the binding of nuclear protein complexes to regions $-3,196$ to

\section{Actinomycin D (hours)}

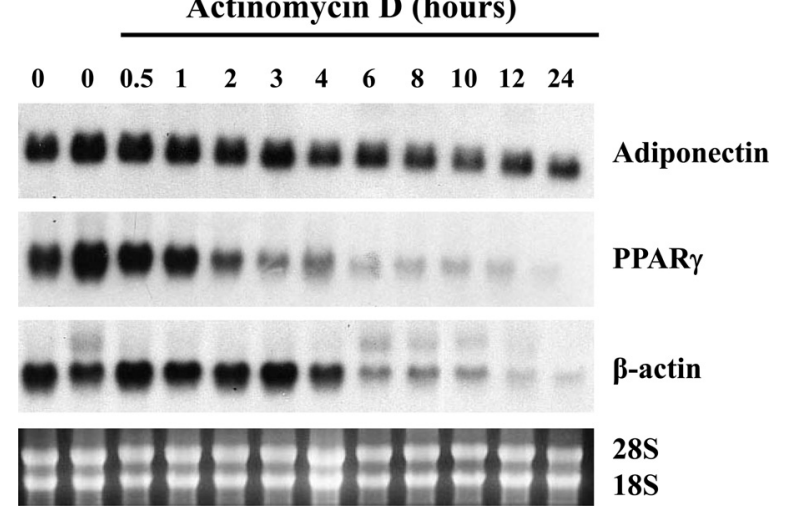

Fig. 3. Adiponectin mRNA is highly stable in adipocytes. Total RNA was isolated from fully differentiated 3T3-L1 adipocytes following treatment with $5 \mu \mathrm{g} / \mathrm{ml}$ actinomycin D for the various periods of time indicated at the top. Control samples were isolated at the start of the experiment (time 0 ). Twenty micrograms of total RNA was electrophoresed, transferred to nylon, and subjected to Northern blot analysis for peroxisome proliferator-activated receptor- $\gamma(\operatorname{PPAR} \gamma)$, adiponectin, and $\beta$-actin. This is a representative experiment independently performed twice. 
Fig. 4. Chronic PRL $(A)$ or GH treatment $(B)$ decreases the expression of adiponectin in 3T3-L1 adipocytes. Fully differentiated 3T3-L1 adipocytes were maintained in DMEM containing 10\% FBS and treated with $1 \mathrm{nM}$ PRL or $2 \mathrm{nM} \mathrm{GH}$ every $24 \mathrm{~h}$ until harvested at the times indicated. Forty micrograms of whole cell extract was subjected to SDS-PAGE and transferred to nitrocellulose for Western blot analysis. STAT5A levels are shown as a loading control. Both $A$ and $B$ represent experiments each performed independently 3 times.

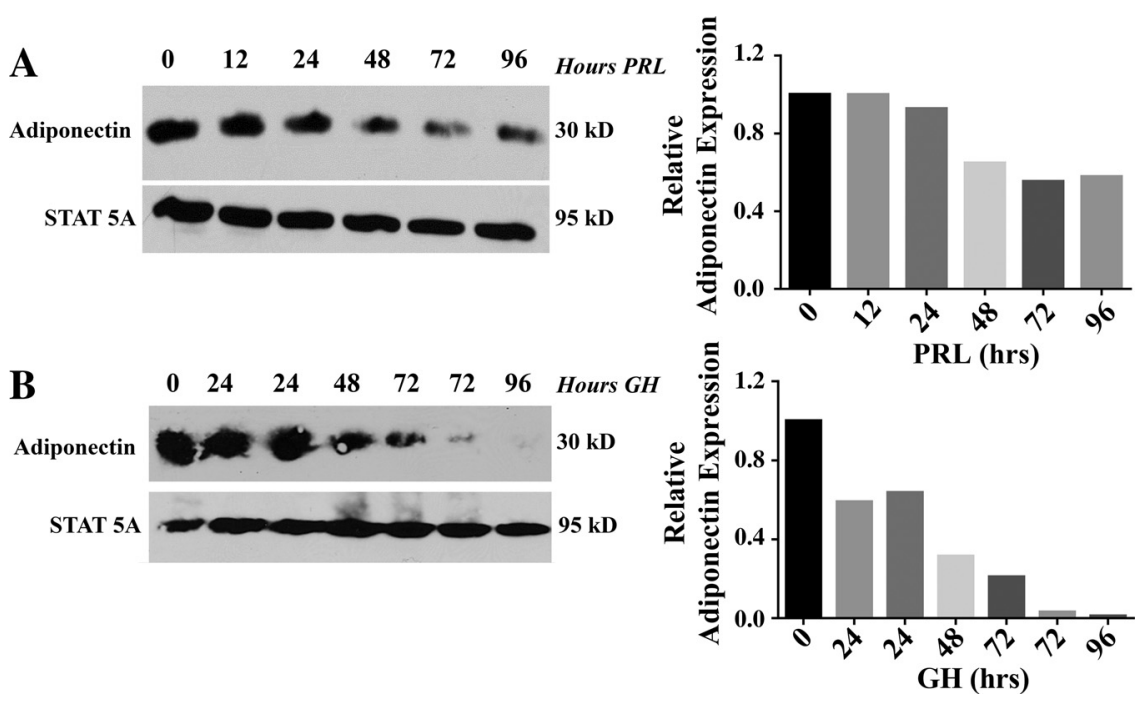

$-3,188$ or $-3,394$ to $-3,386$ of the adiponectin promoter. However, we did observe PRL-induced binding by a nuclear protein complex to the $-3,809$ to $-3,801$ region of the adiponectin promoter. In addition, we observed similar results using GH-treated nuclear extracts (data not shown). The induction of binding by a PRL-activated protein complex to the rat $\beta$-casein STAT5 binding site (47) is included as a positive control. These data demonstrate that one of the three STAT elements in the adiponectin promoter binds nuclear adipocyte protein in a PRL-dependent manner in vitro. To examine the specificity of binding, an EMSA was performed, using a mutant version of the $-3,809$ to $-3,801$ oligonucleotide (see Table 1), in which two nucleotides were changed. As shown in Fig. $1 B$, there was no detectable binding to the mutant form of the binding site following PRL stimulation. In addition, binding of the PRL-activated protein complex was successively competed away with increasing concentrations of the unlabeled $-3,809$ to $-3,801$ oligonucleotide probe (Fig. $1 C$ ). As anticipated, binding was also competed away with the STAT5 binding site of the rat $\beta$-casein promoter.

To determine the specific STAT proteins in the DNA binding complex, we performed supershift analysis using antibodies directed against STAT proteins known to be expressed in adipocytes. As shown in Fig. $1 D$, our data clearly demonstrate that the protein complex induced by PRL was fully supershifted with a STAT5A antibody (lane 4) and weakly supershifted with a STAT5B antibody (lane 5). STAT1 and STAT3 antibodies had no effect on the mobility of the complex (lanes
6 and 7). Highly similar results were also obtained following $\mathrm{GH}$ treatment (data not shown).

Because both GH and PRL were shown to modulate the adiponectin promoter, we observed the effects of $\mathrm{GH}$ on adiponectin RNA. Total RNA was isolated from fully differentiated 3T3-L1 adipocytes after treatment with GH. As shown in Fig. 2, adiponectin mRNA was readily detectable in untreated adipocytes, and $\mathrm{GH}$ had only a modest effect on adiponectin mRNA levels following prolonged $\mathrm{GH}$ treatment. Both ap2 and ethidium bromide staining of 28S and 18S RNA were included as loading controls. Because we did not observe a substantial effect of $\mathrm{GH}$ on adiponectin mRNA, we performed a half-life experiment to determine the longevity of adiponectin mRNA expression. Total RNA was isolated from fully differentiated 3T3-L1 adipocytes after treatment with actinomycin D for the times indicated. As shown in Fig. 3, adiponectin has a relatively long half-life compared with PPAR $\gamma$ and $\beta$-actin. Ethidium bromide staining of $28 \mathrm{~S}$ and 18S RNA is included as a loading control. To our knowledge, this is the first study to demonstrate the stability of the adiponectin mRNA. Additional data indicate that neither $\mathrm{GH}$ or PRL alters the stability of adiponectin mRNA (data not shown).

Several studies have shown that both $\mathrm{GH}$ and PRL can modulate adiponectin levels $(2,3,6,34,40)$. Therefore, we investigated the effects of these STAT5 activators on adiponectin protein levels in fat cells. Mature 3T3-L1 adipocytes were exposed to GH or PRL for various treatment times, and whole
Fig. 5. Adiponectin secretion is decreased by STAT5activating hormones. Mature 3T3-L1 adipocytes were treated daily with a 1-nM dose of PRL, GH, or TNF. Media samples were harvested at the indicated times, and $100 \mu \mathrm{g}$ of each sample was subjected to Western blot analysis. This is a representative experiment performed independently 3 times. CTL, control; Rosi, rosiglitazone; SOD3, superoxide dismutase 3 .
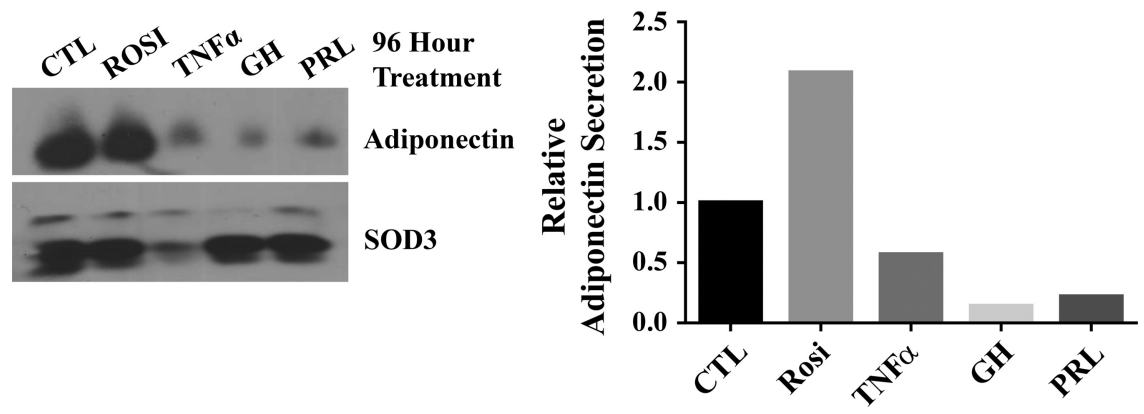
A

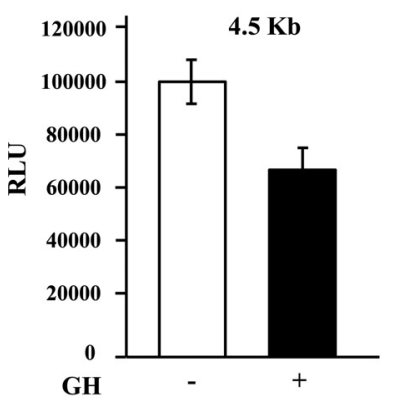

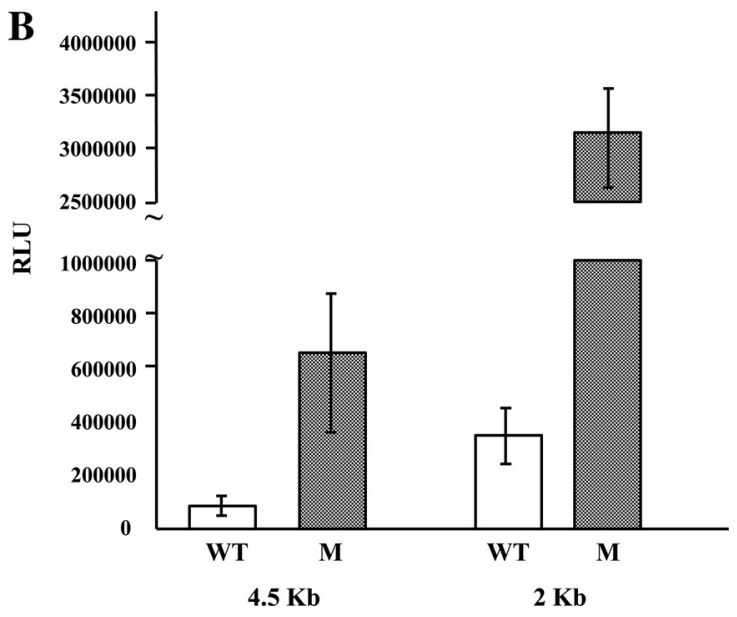

Fig. 6. Treatment with GH modulates adiponectin promoter/reporter construct activity in 3T3-L1 adipocytes. $A$ : fully differentiated adipocytes were transiently transfected with a vector containing $5 \mathrm{~kb}$ of the adiponectin promoter and a firefly luciferase reporter. GH-treated cells were stimulated with $1 \mathrm{nM} \mathrm{GH}$ for $48 \mathrm{~h}$, and a cytomegalovirus/Renilla vector was cotransfected to normalize for transfection efficiency. Relative light units (RLU) were calculated by dividing firefly luciferase activity by Renilla luciferase activity. Each condition was performed in triplicate. In addition, each experiment was performed independently 3 times. $B$ : vectors containing $4.5 \mathrm{~kb}$ or a selected $2 \mathrm{~kb}$ of the adiponectin promoter driving a firefly luciferase reporter were transfected into mature adipocytes. Vectors containing mutants of the $-3,809$ site were also used. cell extracts were isolated to examine adiponectin protein expression. Although neither the 12- nor the 24-h PRL incubations had a substantial effect on adiponectin levels, chronic treatments of 48, 72, and 96 h caused a significant decrease in adiponectin protein (Fig. 4A). STAT5A protein levels are included for even loading. Similar results are shown for $\mathrm{GH}$ in Fig. 4B. Western blot quantitation is shown in Fig. 4, $A$ and $B$, right. We also demonstrated that both $\mathrm{GH}$ and PRL inhibited the secretion of adiponectin following a 96-h incubation of 3T3-L1 adipocytes (Fig. 5). Western blot quantitation is shown in Fig. 5, right. TNF $\alpha$, a proinflammatory cytokine known to downregulate adiponectin expression, was used as a positive control. The thiazolidinedione rosiglitazone was included as a negative control. The levels of the extracellular form of superoxide dismutase 3 were not affected by GH or PRL but were inhibited by $\mathrm{TNF} \alpha$.
Our data demonstrate that STAT5 activators can inhibit adiponectin expression. Therefore, we hypothesized that $\mathrm{GH}$ and PRL may also affect adiponectin promoter activity. Hence, 3T3-L1 cells were transiently transfected with a luciferase construct containing the first $4.5 \mathrm{~kb}$ of the adiponectin promoter. The adipocytes were treated with $\mathrm{GH}$, and after $48 \mathrm{~h}$, luciferase activity was measured as described in MATERIALS AND METHODS. We observed that GH treatment significantly reduced relative luciferase activity, as shown in Fig. $6 \mathrm{~A}$, demonstrating that a $4.5-\mathrm{kb}$ fragment of the adiponectin promoter $(-3,985$ to +503; ENSMUST00000023593) is sensitive to GH. We also made a vector containing $2 \mathrm{~kb}(-3,985$ to $-1,995$; ENSMUST00000023593) of the adiponectin promoter region containing the $-3,809$ to $-3,801$ STAT5A binding site. Transfection of the wild-type and mutant constructs of both the 4.5- and 2-kb promoter/reporter vectors into

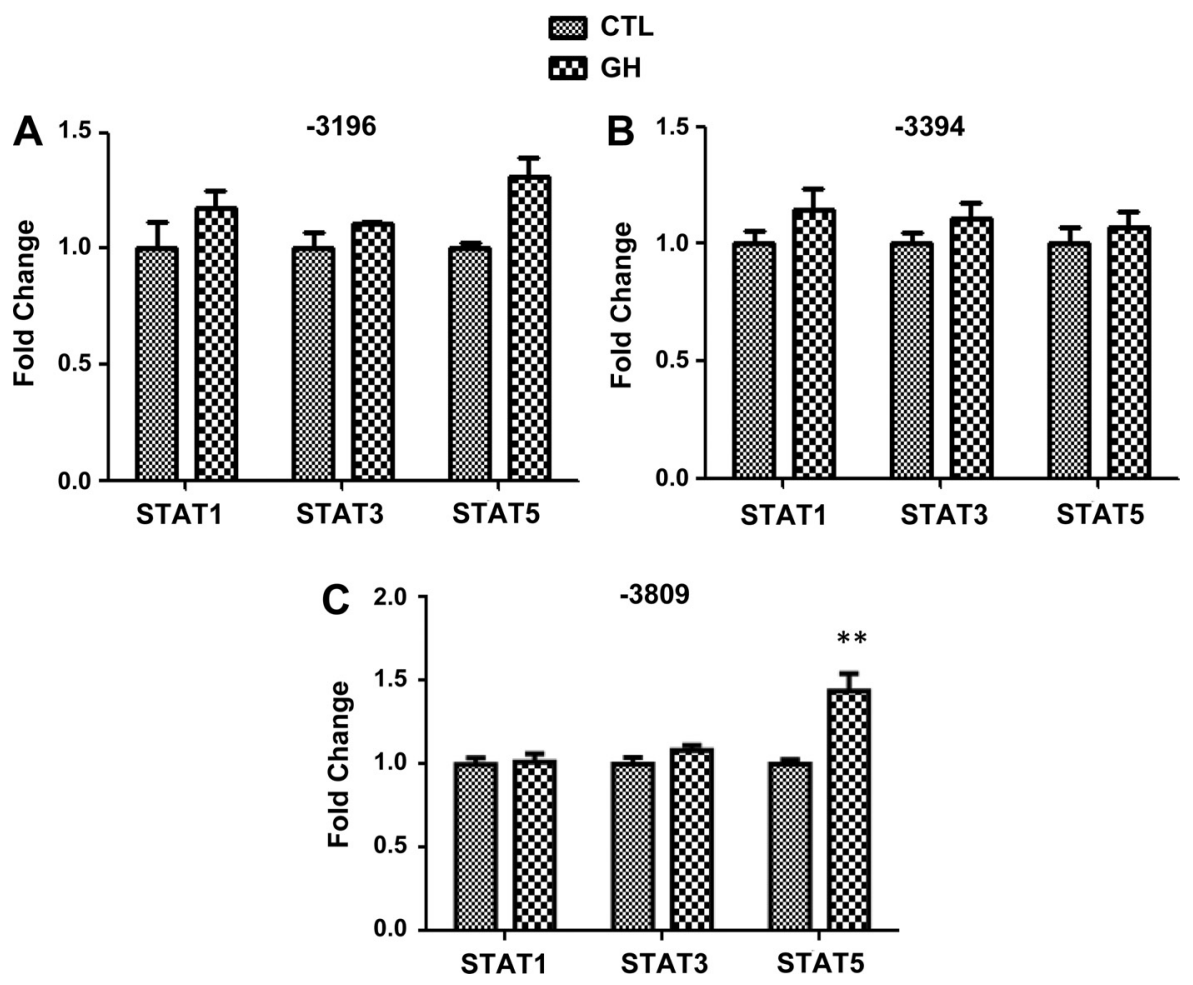

Fig. 7. STAT5A, but not STAT1 and -3, specifically and significantly binds the murine adiponectin promoter in vivo. Mature 3T3-L1 adipocytes were untreated or treated with $1 \mathrm{nM} \mathrm{GH}$ for 30 min and then cross-linked with formaldehyde. Chromatin extracts were prepared and immunoprecipitated with STAT1, STAT3, or STAT5 antibody. Immunoprecipitation products were subjected to quantitative real-time PCR analysis for potential STAT binding sites within the murine adiponectin at promoter regions $-3,196(A),-3,394(B)$, and $-3,809(C)$. The percentage of input was calculated and normalized to the CTL. 
3T3-L1 adipocytes revealed that the basal level of luciferase activity was significantly increased by mutation of the STAT5A binding site in the adiponectin promoter (Fig. 6B). Notably, the activity of the upstream 2-kb fragment was greater than the $4.5-\mathrm{kb}$ construct, suggesting that there are other sites in the proximal promoter that dampen promoter activity. Finally, we performed ChIP analysis to determine whether STAT5 proteins bound to the adiponectin promoter in vivo. As shown in Fig. 7, acute GH treatment resulted in a statistically significant increase in STAT5A binding to the $-3,809$ site we identified and characterized in vitro (Fig. 1). Although there was a modest increase in STAT5A binding to the $-3,196$ site, the changes were not statistically significant. Moreover, we did not observe a statistically significant difference in either STAT1 or STAT3 binding to the putative STAT site in the adiponectin promoter (Fig. 7). Our in vitro and in vivo observations are highly consistent. Overall, these data clearly indicate that the $-3,809$ to $-3,801$ site of the adiponectin promoter is sensitive to $\mathrm{GH}$ and also suggest that this site confers the negative regulation of adiponectin by $\mathrm{GH}-$ and PRL-activated STAT5A protein complexes.

\section{DISCUSSION}

Adiponectin, a hormone produced from adipocytes, is known to enhance insulin sensitivity and have anti-inflammatory actions. Although anterior pituitary hormones like GH and PRL have been shown to reduce adiponectin expression, the mechanism(s) for this regulation was not previously unidentified. We have identified a STAT5A binding site in the murine adiponectin promoter. Collectively, our results demonstrate that the STAT5A binding site in the adiponectin promoter binds STAT5A in vivo and plays a role in decreasing adiponectin promoter activity that eventually results in reduced adiponectin expression and secretion.

An interesting observation that came from our studies was that although acute treatment with STAT5-activating hormones results in the binding of STAT5A to the promoter, it takes several hours of GH or PRL treatment to observe decreased adiponectin mRNA and protein levels. This is likely due to the fact that the adiponectin mRNA is very stable; therefore, there is plenty of adiponectin mRNA accumulated in the cell that continues to be a template for protein synthesis. However, there are likely other transcriptional mediators of adiponectin that act to induce adiponectin promoter activity. The balance of this counterregulation is more challenging to study given the prolonged stability of the adiponectin mRNA.

The promoter region of adiponectin has been studied extensively. SREBP and C/EBP sites in the human adiponectin promoter are required for basal transcription activity $(28,42)$. Occupation of the PPAR $\gamma$ site in the adiponectin promoter is associated with transcriptional activation and induction by thiazolidinediones (24). A liver receptor homolog-1 ite has been shown to be important for basal and induced transcription (24). The forkhead transcription factor $\mathrm{O} 1$ also binds the adiponectin promoter to induce expression (4). Furthermore, nuclear factor $\mathrm{Y}$ modulates the adiponectin promoter, and mutation or deletion of the shared binding site results in dramatically reduced transcription levels (41). To date, all of the transcription factor binding sites in the adiponectin promoter that have been studied are associated with basal tran- scriptional activity or increased transcription. To our knowledge, the STAT5 binding site in the murine adiponectin promoter that is occupied following GH stimulation in vivo is the first to be associated with decreased transcriptional activity of adiponectin. Several single nucleotide polymorphisms that are linked to type 2 diabetes and metabolic syndrome have been identified in the adiponectin promoter $(17,27,37,55,59)$, but none of these include the STAT5 site we have identified.

A key question that arises for this research is whether chronically elevated levels of GH and PRL are associated with decreased adiponectin levels in vivo. In mice, there is no doubt that a loss of $\mathrm{GH}$ or its receptor is associated with increased adiponectin, and mice with excess GH have reduced adiponectin expression (3). Humans with acromegaly or prolactinoma have hypoadiponectinemia $(9,29,52)$, although one study showed an increase in adiponectin levels with acromegaly (49). Future studies will need to address the potential ability of STAT5-activating hormones to inhibit adiponectin in nonadipocyte cells, including those found in skeletal muscle $(5,15)$, the pituitary $(25,26)$, and the pancreas (33). Also, it is largely accepted that the high molecular form of adiponectin is the most cardioprotective. Hence, additional studies to assess the ability of GH and PRL to modulate the high molecular forms of adiponectin should be performed. In humans, there is some evidence that GH treatment reduces the levels of high-molecular weight adiponectin in rodents (22) and humans (23). Despite some modest inconsistencies in the literature, the majority of data support a role for PRL and GH, two STAT5activating hormones, in negatively regulating adiponectin levels. Overall, our data provide mechanistic insight into the transcriptional control of an important hormone that is modulated in metabolic disease.

\section{ACKNOWLEDGMENTS}

We thank Pat Arbour-Reily and Anik Boudreau for technical assistance.

\section{GRANTS}

This work was supported by grant R01-DK-529680 from the National Institute of Diabetes and Digestive and Kidney Diseases to J. M. Stephens.

\section{DISCLOSURES}

No conflicts of interest, financial or otherwise, are declared by the authors.

\section{AUTHOR CONTRIBUTIONS}

U.A.W., P.Z., and J.M.S. conception and design of research; U.A.W., J.M., P.Z., A.J.R., and J.M.S. performed experiments; U.A.W., J.M., P.Z., A.J.R., and J.M.S. analyzed data; U.A.W., P.Z., A.J.R., and J.M.S. interpreted results of experiments; U.A.W., P.Z., and J.M.S. prepared figures; U.A.W. drafted manuscript; U.A.W., P.Z., A.J.R., and J.M.S. edited and revised manuscript; A.J.R. and J.M.S. approved final version of manuscript.

\section{REFERENCES}

1. Arita Y, Kihara S, Ouchi N, Takahashi M, Maeda K, Miyagawa J, Hotta K, Shimomura I, Nakamura T, Miyaoka K, Kuriyama H, Nishida M, Yamashita S, Okubo K, Matsubara K, Muraguchi M, Ohmoto Y, Funahashi T, Matsuzawa Y. Paradoxical decrease of an adipose-specific protein, adiponectin, in obesity. Biochem Biophys Res Commun 257: 79-83, 1999.

2. Asai-Sato M, Okamoto M, Endo M, Yoshida H, Murase M, Ikeda M, Sakakibara H, Takahashi T, Hirahara F. Hypoadiponectinemia in lean lactating women: Prolactin inhibits adiponectin secretion from human adipocytes. Endocr J 53: 555-562, 2006. 
3. Berryman DE, List EO, Coschigano KT, Behar K, Kim JK, Kopchick JJ. Comparing adiposity profiles in three mouse models with altered GH signaling. Growth Horm IGF Res 14: 309-318, 2004.

4. Brunet A, Bonni A, Zigmond MJ, Lin MZ, Juo P, Hu LS, Anderson MJ, Arden KC, Blenis J, Greenberg ME. Akt promotes cell survival by phosphorylating and inhibiting a Forkhead transcription factor. Cell 96: 857-868, 1999.

5. Capllonch-Amer G, Sbert-Roig M, Galmes-Pascual BM, Proenza AM, Llado I, Gianotti M, Garcia-Palmer FJ. Estradiol stimulates mitochondrial biogenesis and adiponectin expression in skeletal muscle. $J$ Endocrinol 221: 391-403, 2014.

6. Combs TP, Berg AH, Rajala MW, Klebanov S, Iyengar P, JimenezChillaron JC, Patti ME, Klein SL, Weinstein RS, Scherer PE. Sexual differentiation, pregnancy, calorie restriction, and aging affect the adipocyte-specific secretory protein adiponectin. Diabetes 52: 268-276, 2003.

7. Coulter AA, Stephens JM. STAT5 activators modulate acyl CoA oxidase (AOX) expression in adipocytes and STAT5A binds to the AOX promoter in vitro. Biochem Biophys Res Commun 344: 1342-1345, 2006.

8. Davidson MB. Effect of growth hormone on carbohydrate and lipid metabolism. Endocr Rev 8: 115-131, 1987.

9. de Assunção Alves Rodrigues LF, Campos SM, Miranda PA, Bizzi MF, Sales do Amaral PH, Giannetti AV, Ribeiro-Oliveira A. Prolactinoma: a condition associated with hypoadiponectinemia. Horm Metab Res 44: 832-838, 2012.

10. Fain JN, Ihle JH, Bahouth SW. Stimulation of lipolysis but not of leptin release by growth hormone is abolished in adipose tissue from Stat5a and b knockout mice. Biochem Biophys Res Commun 263: 201-205, 1999.

11. Fielder PJ, Talamantes F. The lipolytic effects of mouse placental lactogen II, mouse prolactin, and mouse growth hormone on adipose tissue from virgin and pregnant mice. Endocrinology 121: 493-497, 1987.

12. Floyd ZE, Stephens JM. STAT5A promotes adipogenesis in nonprecursor cells and associates with the glucocorticoid receptor during adipocyte differentiation. Diabetes 52: 308-314, 2003.

13. Fruebis J, Tsao TS, Javorschi S, Ebbets-Reed D, Erickson MR, Yen FT, Bihain BE, Lodish HF. Proteolytic cleavage product of $30-\mathrm{kDa}$ adipocyte complement-related protein increases fatty acid oxidation in muscle and causes weight loss in mice. Proc Natl Acad Sci USA 98: 2005-2010, 2001.

14. Ginis Z, Ucar F, Erdogan S, Ozturk G, Akyol S, Erden G, Arslan MS, Delibasi T. Serum vaspin and adiponectin levels in patients with prolactinoma. Scand J Clin Lab Invest 28: 1-8, 2015.

15. Goto A, Ohno Y, Ikuta A, Suzuki M, Ohira T, Egawa T, Sugiura T, Yoshioka T, Ohira Y, Goto K. Up-regulation of adiponectin expression in antigravitational soleus muscle in response to unloading followed by reloading, and functional overloading in mice. PLoS One 8: e81929, 2013.

16. Haluzik M, Parizkova J, Haluzik MM. Adiponectin and its role in the obesity-induced insulin resistance and related complications. Physiol Res 53: 123-129, 2004.

17. Hara K, Boutin P, Mori Y, Tobe K, Dina C, Yasuda K, Yamauchi T, Otabe S, Okada T, Eto K, Kadowaki H, Hagura R, Akanuma Y, Yazaki Y, Nagai R, Taniyama M, Matsubara K, Yoda M, Nakano Y, Tomita M, Kimura S, Ito C, Froguel P, Kadowaki T. Genetic variation in the gene encoding adiponectin is associated with an increased risk of type 2 diabetes in the Japanese population. Diabetes 51: 536-540, 2002.

18. Hogan JC, Stephens JM. The regulation of fatty acid synthase by STAT5A. Diabetes 54: 1968-1975, 2005.

19. Hotta K, Funahashi T, Arita Y, Takahashi M, Matsuda M, Okamoto Y, Iwahashi H, Kuriyama H, Ouchi N, Maeda K, Nishida M, Kihara S, Sakai N, Nakajima T, Hasegawa K, Muraguchi M, Ohmoto Y, Nakamura T, Yamashita S, Hanafusa T, Matsuzawa Y. Plasma concentrations of a novel, adipose-specific protein, adiponectin, in type 2 diabetic patients. Arterioscler Thromb Vasc Biol 20: 1595-1599, 2000.

20. Hotta K, Funahashi T, Bodkin NL, Ortmeyer HK, Arita Y, Hansen BC, Matsuzawa Y. Circulating concentrations of the adipocyte protein adiponectin are decreased in parallel with reduced insulin sensitivity during the progression to type 2 diabetes in rhesus monkeys. Diabetes 50 : $1126-1133,2001$

21. Hu E, Liang P, Spiegelman BM. AdipoQ is a novel adipose-specific gene dysregulated in obesity. J Biol Chem 271: 10697-10703, 1996.

22. Huang D, Yang C, Wang Y, Liao Y, Huang K. PARP-1 suppresses adiponectin expression through poly(ADP-ribosyl)ation of PPAR gamma in cardiac fibroblasts. Cardiovasc Res 81: 98-107, 2009.
23. Ibáñez L, Lopez-Bermejo A, Díaz M, Jaramillo A, Marín S, de Zegher F. Growth hormone therapy in short children born small for gestational age: effects on abdominal fat partitioning and circulating follistatin and high-molecular-weight adiponectin. J Clin Endocrinol Metab 95: 2234 2239, 2010.

24. Iwaki M, Matsuda M, Maeda N, Funahashi T, Matsuzawa Y, Makishima M, Shimomura I. Induction of adiponectin, a fat-derived antidiabetic and antiatherogenic factor, by nuclear receptors. Diabetes 52: 1655-1663, 2003.

25. Kiezun M, Smolinska N, Maleszka A, Dobrzyn K, Szeszko K, Kaminski T. Adiponectin expression in the porcine pituitary during the estrous cycle and its effect on LH and FSH secretion. Am J Physiol Endocrinol Metab 307: E1038-E1046, 2014.

26. Kim J, Zheng W, Grafer C, Mann ML, Halvorson LM. GnRH decreases adiponectin expression in pituitary gonadotropes via the calcium and PKA pathways. Reprod Sci 20: 937-945, 2013.

27. Kissebah AH, Sonnenberg GE, Myklebust J, Goldstein M, Broman K, James RG, Marks JA, Krakower GR, Jacob HJ, Weber J, Martin L, Blangero J, Comuzzie AG. Quantitative trait loci on chromosomes 3 and 17 influence phenotypes of the metabolic syndrome. Proc Natl Acad Sci USA 97: 14478-14483, 2000.

28. Kita A, Yamasaki H, Kuwahara H, Moriuchi A, Fukushima K, Kobayashi M, Fukushima T, Takahashi R, Abiru N, Uotani S, Kawasaki E, Eguchi K. Identification of the promoter region required for human adiponectin gene transcription: Association with CCAAT/enhancer binding protein-beta and tumor necrosis factor-alpha. Biochem Biophys Res Commun 331: 484-490, 2005.

29. Lam KS, Xu A, Tan KC, Wong LC, Tiu SC, Tam S. Serum adiponectin is reduced in acromegaly and normalized after correction of growth hormone excess. J Clin Endocrinol Metab 89: 5448-5453, 2004.

30. Lihn AS, Bruun JM, He G, Pedersen SB, Jensen PF, Richelsen B. Lower expression of adiponectin mRNA in visceral adipose tissue in lean and obese subjects. Mol Cell Endocrinol 219: 9-15, 2004.

31. Ling C, Hellgren G, Gebre-Medhin M, Dillner K, Wennbo H, Carlsson B, Billig H. Prolactin (PRL) receptor gene expression in mouse adipose tissue: increases during lactation and in PRL-transgenic mice. Endocrinology 141: 3564-3572, 2000.

32. Ling C, Svensson L, Oden B, Weijdegard B, Eden B, Eden S, Billig $\mathbf{H}$. Identification of functional prolactin (PRL) receptor gene expression: PRL inhibits lipoprotein lipase activity in human white adipose tissue. $J$ Clin Endocrinol Metab 88: 1804-1808, 2003.

33. Liu XX, Liu KY, Li P, Han S, Peng XD, Shen L. Adiponectin is expressed in the pancreas of high-fat-diet-fed mice and protects pancreatic endothelial function during the development of type 2 diabetes. Diabetes Metab 40: 363-372, 2014.

34. Lubbers ER, List EO, Jara A, Sackman-Sala L, Cordoba-Chacon J, Gahete MD, Kineman RD, Boparai R, Bartke A, Kopchick JJ, Berryman DE. Adiponectin in mice with altered GH action: links to insulin sensitivity and longevity? J Endocrinol 216: 363-374, 2013.

35. Magri KA, Adamo M, Leroith D, Etherton TD. The inhibition of insulin action and glucose metabolism by porcine growth hormone in porcine adipocytes is not the result of any decrease in insulin binding or insulin receptor kinase activity. Biochem J 266: 107-113, 1990.

36. McAveney KM, Gimble JM, Yu-Lee L. Prolactin receptor expression during adipocyte differentiation of bone marrow stroma. Endocrinology 137: 5723-5726, 1996.

37. Mori Y, Otabe S, Dina C, Yasuda K, Populaire C, Lecoeur C, Vatin V, Durand E, Hara K, Okada T, Tobe K, Boutin P, Kadowaki T, Froguel P. Genome-wide search for type 2 diabetes in Japanese affected sib-pairs confirms susceptibility genes on $3 \mathrm{q}, 15 \mathrm{q}$, and $20 \mathrm{q}$ and identifies two new candidate Loci on 7p and 11p. Diabetes 51: 1247-1255, 2002.

38. Nanbu-Wakao R, Morikawa Y, Matsumura I, Masuho Y, Muramatsu MA, Senba E, Wakao H. Stimulation of 3T3-L1 adipogenesis by signal transducer and activator of transcription 5. Mol Endocrinol 16: 15651576, 2002.

39. Nawrocki AR, Rajala MW, Tomas E, Pajvani UB, Saha AK, Trumbauer ME, Pang Z, Chen AS, Ruderman NB, Chen H, Rossetti L, Scherer PE. Mice lacking adiponectin show decreased hepatic insulin sensitivity and reduced responsiveness to peroxisome proliferator-activated receptor gamma agonists. J Biol Chem 281: 2654-2660, 2006.

40. Nilsson L, Binart N, Bohlooly Y, Bramnert M, Egecioglu E, Kindblom J, Kelly PA, Kopchick JJ, Ormandy CJ, Ling C, Billig H. Prolactin and growth hormone regulate adiponectin secretion and receptor expression in adipose tissue. Biochem Biophys Res Commun 331: 1120-1126, 2005. 
41. Park SK, Oh SY, Lee MY, Yoon S, Kim KS, Kim JW. CCAAT/ enhancer binding protein and nuclear factor-Y regulate adiponectin gene expression in adipose tissue. Diabetes 53: 2757-2766, 2004.

42. Qiao L, Maclean PS, Schaack J, Orlicky DJ, Darimont C, Pagliassotti M, Friedman JE, Shao J. C/EBPalpha regulates human adiponectin gene transcription through an intronic enhancer. Diabetes 54: 1744-1754, 2005.

43. Richter HE, Albrektsen T, Billestrup N. The role of signal transducer and activator of transcription 5 in the inhibitory effects of $\mathrm{GH}$ on adipocyte differentiation. J Mol Endocrinol 30: 139-150, 2003.

44. Ritzenthaler JD, Goldstein RH, Fine A, Lichtler A, Rowe DW, Smith BD. Transforming-growth-factor-beta activation elements in the distal promoter regions of the rat alpha 1 type I collagen gene. Biochem J 280: 157-162, 1991.

45. Scherer PE, Williams S, Fogliano M, Baldini G, Lodish HF. A novel serum protein similar to $\mathrm{C} 1 \mathrm{q}$, produced exclusively in adipocytes. $J$ Biol Chem 270: 26746-26749, 1995.

46. Schindler C. Cytokines and JAK-STAT signaling. Exp Cell Res 253: 7-14, 1999.

47. Schmitt-Ney M, Doppler W, Ball RK, Groner B. Beta-casein gene promoter activity is regulated by the hormone-mediated relief of transcriptional repression and a mammary-gland-specific nuclear factor. $\mathrm{Mol} \mathrm{Cell}$ Biol 11: 3745-3755, 1991.

48. Shang CA, Waters MJ. Constitutively active signal transducer and activator of transcription 5 can replace the requirement for growth hormone in adipogenesis of 3T3-F442A preadipocytes. Mol Endocrinol 17: 2494-2508, 2003.

49. Silha JV, Krsek M, Hana V, Marek J, Jezkova J, Weiss V, Murphy LJ. Perturbations in adiponectin, leptin and resistin levels in acromegaly: lack of correlation with insulin resistance. Clin Endocrinol 58: 736-742, 2003.

50. Stephens JM, Morrison RF, Wu Z, Farmer SR. PPARgamma liganddependent induction of STAT1, STAT5A, and STAT5B during adipogenesis. Biochem Biophys Res Commun 262: 216-222, 1999.

51. Stewart WC, Pearcyl LA, Floyd ZE, Stephens JM. STAT5A expression in Swiss 3 T3 cells promotes adipogenesis in vivo in an athymic mice model system. Obesity (Silver Spring) 19: 1731-1734, 2011.
52. Sucunza N, Barahona MJ, Resmini E, Fernández-Real JM, Ricart W, Farrerons J, Rodríguez Espinosa J, Marin AM, Puig T, Webb SM. A link between bone mineral density and serum adiponectin and visfatin levels in acromegaly. J Clin Endocrinol Metab 94: 3889-3896, 2009.

53. Teglund S, McKay C, Schuetz E, van Deursen JM, Stravopodis D, Wang D, Brown M, Bodner S, Grosveld G, Ihle JN. Stat5a and Stat5b proteins have essential and nonessential, or redundant, roles in cytokine responses. Cell 93: 841-850, 1998.

54. Turer AT, Scherer PE. Adiponectin: mechanistic insights and clinical implications. Diabetologia 55: 2319-2326, 2012.

55. Vasseur F, Helbecque N, Dina C, Lobbens S, Delannoy V, Gaget S, Boutin P, Vaxillaire M, Leprêtre F, Dupont S, Hara K, Clément K, Bihain B, Kadowaki T, Froguel P. Single-nucleotide polymorphism haplotypes in the both proximal promoter and exon 3 of the APM1 gene modulate adipocyte-secreted adiponectin hormone levels and contribute to the genetic risk for type 2 diabetes in French Caucasians. Hum Mol Genet 11: 2607-2614, 2002.

56. Wabitsch M, Braun S, Hauner H, Heinze E, Ilondo MM, Shymko R, De Meyts P, Teller WM. Mitogenic and antiadipogenic properties of human growth hormone in differentiating human adipocyte precursor cells in primary culture. Pediatr Res 40: 450-456, 1996.

57. White UA, Coulter AA, Miles TK, Stephens JM. The STAT5Amediated induction of pyruvate dehydrogenase kinase 4 expression by prolactin or growth hormone in adipocytes. Diabetes 56: 1623-1629, 2007.

58. Yarwood SJ, Sale EM, Sale GJ, Houslay MD, Kilgour E, Anderson NG. Growth hormone-dependent differentiation of 3T3-F442A preadipocytes requires Janus kinase/signal transducer and activator of transcription but not mitogen-activated protein kinase or p70 S6 kinase signaling. J Biol Chem 274: 8662-8668, 1999.

59. Zacharova J, Chiasson JL, Laakso M; STOP-NIDDM Study Group. The common polymorphisms (single nucleotide polymorphism [SNP] +45 and SNP +276) of the adiponectin gene predict the conversion from impaired glucose tolerance to type 2 diabetes: the STOP-NIDDM trial. Diabetes 54: 893-899, 2005.

60. Zvonic S, Cornelius P, Stewart WC, Mynatt RL, Stephens JM. The regulation and activation of ciliary neurotrophic factor signaling proteins in adipocytes. J Biol Chem 278: 2228-2235, 2003. 